\title{
Current Opinions on Forensic Accounting Education
}

\section{Authors: Bonita Kramer, Michael Seda, and Georgiy Bobachev}

This is a postprint of an article that originally appeared in Accounting Research Journal on January 2018. The final version can be found at https://dx.doi.org/10.1108/ARJ-06-2015-0082.

Kramer, Bonita, Michael Seda, and Georgiy Bobashev. "Current Opinions on Forensic Accounting Education." Accounting Research Journal 30, no. 3 (January 2016): 249-264. DOI:10.1108/ARJ-06-2015-0082.

Made available through Montana State University's ScholarWorks scholarworks.montana.edu 


\title{
Current opinions on forensic accounting education
}

\author{
Bonita Kramer \\ Jake Jabs College of Business and Entrepreneurship, Montana State University, \\ Bozeman, Montana, USA \\ Michael Seda \\ School of Business, Stockton University, Galloway, New Jersey, USA, and \\ Georgiy Bobashev \\ Center for Data Science, RTI International, Research Triangle Park, \\ North Carolina, USA
}

\begin{abstract}
Purpose - This paper aims to determine current views of educators and practitioners regarding forensic accounting education, given the recent dramatic growth in the number of colleges and universities offering such education.
\end{abstract}

Design/methodology/approach - Survey, with statistical analysis of responses.

Findings - Results find that while both groups agree the demand for forensic accounting services will increase in the near future and that they prefer a separate course or degree be offered at the graduate and undergraduate levels, there are several significant differences between the educators' and practitioners' opinions on forensic accounting content and preferred teaching techniques. Practitioners consider topics outside traditional accounting as more important to include in forensic accounting education, and more highly value teaching techniques that add an experiential learning component.

Practical implications - Results can be useful to educators who have not considered offering forensic accounting courses or who wish to refine or update their existing forensic accounting education. Students seeking a career in forensic accounting can also use these results to facilitate their course choices to develop skills that employers value.

Social implications - These results find that practitioners value some nontraditional accounting skills, such as in forensic technology and interviewing, more highly than academics, which suggests accounting educators may need to develop interdisciplinary approaches to forensic accounting education.

Originality/value - As the number of institutions offering forensic accounting education has dramatically increased, current views of forensic accounting educators and practitioners are needed.

Keywords Fraud, Forensic accounting, Accounting curriculum, Educator survey,

Practitioner survey

Paper type Research paper

Shortly after the widely publicized financial reporting scandals of Enron, WorldCom, HealthSouth, etc., leaders in the accounting profession began to call for accounting educators to provide forensic accounting education (Carozza, 2002; Melancon, 2002). Research around that time found very few universities offered courses, much less degrees, in that field (Buckhoff and Schrader, 2000; Peterson and Reider, 2001; Peterson and Buckhoff, 2004). Current research has found that the extent of forensic accounting education has increased tremendously (Seda and Kramer, 2014). Not only are hundreds of universities now offering a specific course on forensic accounting and/or fraud 
examination, but many universities now also offer a specific degree, minor and/or certificate in this field[1].

Given the significant increase in the availability of forensic accounting education and the importance of knowledge of this topic to the future careers of today's accounting students, this paper surveys academicians and practitioners to determine their current opinions related to forensic accounting education. These results can aid educators in developing or improving their curriculum choices in this area, assist students interested in this career path in choosing courses that will develop highly marketable skills and underscore the importance of an interdisciplinary approach to forensic accounting education.

The remainder of this paper is organized as follows. First, a review of the existing literature is presented, followed by a discussion of the research method. Next, results are presented with a discussion of the implications of the findings, followed by concluding remarks including limitations and suggestions for future research.

\section{Literature review}

\section{Forensic accounting education: need and benefits}

International fraud and economic crime surveys consistently report that fraud is a serious problem affecting organizations, without regard to geographical location, size or industry (ACFE, 2014; E\&Y, 2014; PwC, 2014; KPMG, 2013). A constant finding is the most common way of discovering a fraud is through a tip, regardless of the source (e.g. employee, vendor, customer or anonymous). Further, the surveys report that external auditors rarely discover a fraud because many times it may not be causing financial statements to be materially misstated. Owing to the significant amount of employee and management fraud, embezzlement and other financial crimes occurring in today's society, accounting and auditing professionals must have appropriate forensic accounting training and skills to recognize those crimes (Houck et al., 2006). These facts underscore the necessity for courses specifically focused on forensic accounting, rather than assuming auditing courses provide sufficient training.

Beyond benefiting society by providing forensic accounting education, students who acquire this knowledge directly benefit. Empirical evidence has been found that hiring potential is enhanced when a candidate has completed a forensic accounting course (Mounce and Frazier, 2002). As far back as 1991, the national placement director for one of the largest recruiters of accountants, financial personnel and information specialists stated that forensic accounting "is the hottest field in accounting firms" with salaries ranging from $\$ 50,000$ to $\$ 200,000$ (Fowler, 1991). A few years later, an article in The Wall Street Journal labeled forensic accountants as the accounting profession's "new glamour kids" and reported that not only did the Federal Bureau of Investigation (FBI) double its forensic accountant agent force between 1992 and 1996, but several large public accounting firms doubled or even quintupled their forensic ranks (MacDonald, 1996). A cover story in USA News \& World Report included forensic accountant as one of the eight most secure career tracks in the country (Levine, 2002). The article reported that 40 per cent of the top 100 accounting firms were expanding their forensic accounting consulting services.

Demand for forensic accountants remains strong today and continues to grow (Cohn, 2014; White, 2013; Tysiac, 2012). Employment opportunities are abundant and include public accounting, loss prevention/security, internal audit, law enforcement and a number of federal agencies, such as the FBI and the Internal Revenue Service. Even if students never choose a forensic accounting career path, the skills they learn will make them better business professionals, whether they work as an auditor, manager or consultant. For example, Carpenter et al. (2011) provide empirical evidence that students who completed a 
forensic accounting course possess more professional skepticism than students without such training, and that this effect persists over time.

\section{Evolution of forensic accounting education availability}

Over a decade ago, leaders in the accounting profession began to call for educators to provide forensic accounting education, owing in part to widely publicized financial reporting scandals and the scarcity of schools providing this education (Melancon, 2002). Academia had largely ignored the field. Academic articles focusing on forensic accounting education were rare prior to the late 1990s (Rebele et al., 1998). One of the earliest studies, Rezaee et al. (1996), identified only four universities that offered a separate forensic accounting course.

Buckhoff and Schrader (2000) found 13 universities offered a separate forensic accounting course, consistent with what was found by another independent study (Peterson and Reider, 1999). Combining those two studies, Peterson and Reider (2001) identified 19 universities offering a forensic accounting course and reviewed the syllabi for similarities and differences in content and learning activities.

Carnes and Gierlasinski (2001) reported that universities were slow in providing forensic accounting education to students, even though the changing accounting environment was demanding students be taught these skills. Bundy et al. (2003) noted that forensic accounting was a new growth industry in accounting, and found only two US colleges offered an undergraduate degree in a related field: economic crime investigation.

Rezaee et al. (2004) found small improvement in the availability of forensic accounting education, identifying 25 universities that offered a separate forensic accounting course. At approximately this same time, in 2003, West Virginia University (WVU) received a significant grant from the National Institute of Justice to develop a model curriculum in forensic accounting in collaboration with a technical working group comprising 46 subjectmatter experts from a variety of stakeholder groups (WVU, 2007). WVU developed the grant proposal because only a few schools were offering multiple courses in the forensic accounting field, with great variation in course content.

In a review of accounting education literature published in six academic journals over four years, Apostolou et al. (2010, p. 181) note, "[...]in 2006-2009, an increase in articles related to fraud and forensic issues and ethics reflects the changing emphasis on these topics". Articles began to appear that recommended forensic accounting subject matter content, such as behavioral sciences (Ramamoorti, 2008), ethics and legal/regulatory environments (Curtis, 2008), digital forensics (Pearson and Singleton, 2008) and litigation advisory services (Heitger and Heitger, 2008).

Later studies generally found an increase in the number of colleges and universities offering forensic accounting education. For example, Seda and Kramer (2009) identified 48 universities and colleges that offered a separate forensic accounting course and found another 21 institutions with various forensic accounting programs at the undergraduate and graduate levels (degrees, minors and/or certificates). Smith and Crumbley (2009) found 40 universities with one to six forensic accounting courses offered.

Seda and Kramer (2014) found significantly more colleges and universities providing forensic accounting education. They identified 447 colleges and universities in the USA and internationally that offer at least a single forensic accounting course, 81 with a forensic accounting certificate or degree program and 106 with a forensic accounting concentration or minor. These results finding significantly more forensic accounting education availability may be owing to any combination of the following factors: 
- the research was conducted more recently;

- a sample was not taken, but rather, all universities and colleges listed in two fairly comprehensive sources were researched; and

- the study did not limit itself to the USA, but focused on international forensic accounting education.

Published research clearly shows a significant increase in the availability of forensic accounting education during the past two decades.

\section{Views of forensic accounting education stakeholders}

A body of literature exists that focuses, instead, on the views of various stakeholders in forensic accounting education, such as certified public accountants (CPAs), certified fraud examiners (CFEs), users of forensic accounting services and academicians.

Rezaee et al. (2004) surveyed academicians and CPAs to determine their perceived benefits of providing forensic accounting education. While both groups agreed forensic accounting education can prepare students to engage in fraud examination, the groups differed in their opinions on whether forensic accounting education prepares students to engage in two other major forensic accounting areas: litigation support consulting and expert witnessing.

Meservy et al. (2006) surveyed CFEs and found they identified several critical forensic accounting skills that were not being taught in accounting programs: interrogation and interviewing skills, evidence sources, fraudulent financial statement schemes, criminology, computer/internet fraud techniques or skills and people/human relations skills.

DiGabriele (2008) surveyed forensic accounting practitioners, accounting academics and users of forensic accounting services for views on relevant skills needed by forensic accountants. He found that respondents believe a forensic accountant should possess skills in critical thinking, unstructured problem-solving, investigative flexibility, analytical proficiency, oral and written communication and deductive analysis. In addition, respondents also considered legal knowledge and the ability to maintain composure to be important.

Davis et al. (2009) surveyed academics, attorneys and CPAs to determine the characteristics and skills needed by forensic accountants. They found analytical skills are the foremost trait, but the forensic accountant also needs to look beyond the analytical details and see the big picture. In addition, communication skills, the ability to simplify a complex issue and the ability to present opinions in a legal setting are also critical skills.

McMullan and Sanchez (2010) surveyed forensic professionals for their perceptions of the characteristics, skills and education necessary for forensic accountants. The ability ranked as most important is analytical skills, followed by expertise in basic accounting, problemsolving and data analysis. The most important characteristics are persistence, skepticism, puzzle skills and people skills.

Thus, the available research finds no dispute regarding the need to offer forensic accounting education. However, despite the fact that there has been dramatic growth in the availability of this education, there have been no current studies on views of practitioners and educators regarding forensic accounting education. Consequently, this paper conducts a survey to determine current views on a variety of forensic accounting education issues among practitioners and academicians.

\section{Research method}

A total of 740 accounting academicians who primarily teach forensic accounting and/or auditing were randomly selected from the Hasselback Accounting Faculty Directory 
(Hasselback, 2015) to complete an online survey of 11 questions relating to forensic accounting education. In addition, this paper surveyed 40 practitioners attending a forensic accounting training seminar and asked them to complete a slightly shorter online questionnaire of nine questions. To improve the response rate, an e-mail was sent containing the survey link and the research objectives, while assuring confidentiality of individual responses. In addition to agreeing to share a summary of findings, the e-mail gave the approximate time needed to complete the questionnaire, and offered the opportunity to enter a drawing for one of five $\$ 50$ Amazon gift cards. Finally, a second e-mail reminder was sent approximately two weeks later.

Further, while the topic of forensic accounting education is broad, the survey limited the number of questions to encourage a higher response rate. Questions were selected after a review of the literature previously discussed, in addition to a review of current forensic accounting textbooks (Crumbley et al., 2013; Hopwood et al., 2012).

The survey instrument was pilot-tested by sending it to a few academic colleagues to review. Their suggestions were incorporated into the final questionnaire, which primarily related to wording and organization.

Demographics and response rates are shown in Table I. While the response rate from academicians is lower than what might be desired, it is consistent with prior studies (Seda and Kramer, 2008; Rezaee et al., 2004; DiGabriele, 2008). To test for a nonresponse bias, earlier responses were compared to later responses and no significant differences were noted.

\section{Results}

Statistical analysis

A univariate analysis was conducted where the response distributions were examined. The answers for most questions are five-level scale variables, so for the comparison analysis of the means, they could be potentially treated in several ways: proportional odds (chi-square test), continuous scale ( $t$-test) and categorical (chi-square). However, for the ordered categories and an unbalanced sample, a nonparametric Kruskal-Wallis test has a better power. A multiple comparison adjustment was also applied to account for the fact that this paper was conducting multiple tests for the same group. The Holm adjustment (Holm, 1979; Shaffer, 1995), which is similar to the Bonferroni adjustment but is uniformly more powerful, was used. A sensitivity analysis comparing the test results from the different methods was conducted, and while the actual values slightly differ, the overall significance remains robust.

\begin{tabular}{|c|c|c|c|c|c|}
\hline $\begin{array}{l}\text { Number of surveys and } \\
\text { demographics }\end{array}$ & \multicolumn{2}{|c|}{ Academicians } & \multicolumn{2}{|c|}{ Practitioners } & \\
\hline \multirow{7}{*}{$\begin{array}{l}\text { Surveys } \\
\text { Responses (rate) } \\
\text { Job title } \\
\text { (\% rounded) }\end{array}$} & \multirow{2}{*}{\multicolumn{2}{|c|}{$\begin{array}{c}740 \\
103(14 \%)\end{array}$}} & \multirow{2}{*}{\multicolumn{2}{|c|}{$\begin{array}{c}40 \\
26(65 \%)\end{array}$}} & \\
\hline & & & & & \\
\hline & Full Professor & $39(38 \%)$ & Fraud Investigator & $9(35 \%)$ & \\
\hline & Associate Professor & $17(16 \%)$ & Internal Auditor & $9(35 \%)$ & \\
\hline & Assistant Professor & $16(16 \%)$ & Law Enforcement & $2(7 \%)$ & \\
\hline & Other & $19(18 \%)$ & Controller & $1(4 \%)$ & \\
\hline & No response & $12(12 \%)$ & No response & $5(19 \%)$ & \\
\hline \multirow[t]{2}{*}{ Location (\%) } & USA & $93(90 \%)$ & USA & $26(100 \%)$ & Table I. \\
\hline & Other countries & $10(10 \%)$ & Other countries & 0 & Demographic \\
\hline \multicolumn{4}{|c|}{ Average number of years of forensic accounting experience } & 19.4 years & information \\
\hline
\end{tabular}




\section{Expected demand for forensic accounting services}

Table II presents the results of the respondents' views on future demand for three major areas of forensic accounting services (litigation support, expert witnessing and fraud examination).

A large majority of both practitioners and educators expect demand to increase for those services within the next five years. The only significant difference between groups is for fraud examination services, where a larger percentage of practitioners expect increased demand. This difference may be owing to the fact that the practitioners are working in the field and undoubtedly run into fraud cases more often than educators, thus affecting their perception. None of the practitioners expects demand to decrease in any of the three areas.

At the end of the survey, respondents were invited to include any open-ended comments pertaining to any of the questions. Underscoring these results of expecting increased demand, a representative practitioner comment follows:

Our office has over 2,000 cases in litigation support. We provide reports to law firms in divorce and other court cases involving business valuation and finding hidden assets.

A representative educator comment is:

All you need to do is open your local paper each day to be reminded how important it is for students to be aware of, and trained in, the field of forensic accounting. The number of frauds that occur on a daily basis is alarming - and getting worse every day. From the large investment frauds to smaller embezzlement frauds, victims are screaming for help. The accounting professional - trained in the area of forensics - can be an invaluable asset to all areas of society.

\section{Forensic accounting curriculum placement}

Respondents were asked for their opinion on how forensic accounting should be integrated into the curriculum, and results are shown in Table III.

The rankings are identical, with both groups agreeing that a separate course is the most ideal manner by which forensic accounting education should be offered. Not all respondents felt that way, however, as indicated by this educator's comment:

I believe a course that incorporates most forensic accounting topics into auditing classes make more sense. I think of this as a necessary part of every auditor's education, not as something extra or separate.

Not one person in either group believed forensic accounting should not be offered at all. A larger percentage of practitioners thought a separate forensic accounting concentration, major, minor or certificate should be available; forensic accounting should be integrated throughout the accounting curriculum; or a specific master's degree should be offered.

Table II.

Expected demand for different types of forensic accounting services within the next five years

\begin{tabular}{|c|c|c|c|c|c|c|}
\hline \multirow{2}{*}{$\begin{array}{l}\text { Expected demand for } \\
\text { forensic accounting services }\end{array}$} & \multicolumn{2}{|c|}{ Litigation support } & \multicolumn{2}{|c|}{ Expert witnessing } & \multicolumn{2}{|c|}{ Fraud examination } \\
\hline & Educators & Practitioners & Educators & Practitioners & Educators & Practitioners \\
\hline Increased demand & & $22(84.6 \%)$ & $67(65.1 \%)$ & $22(84.6 \%)$ & $78(75.7 \%)$ & $25(96.1 \%)$ \\
\hline No change in demand & $19(18.5 \%)$ & $2(7.7 \%)$ & $27(26.2 \%)$ & $3(11.5 \%)$ & $19(18.5 \%)$ & $1(3.9 \%)$ \\
\hline Decreased demand & $1(0.9 \%)$ & $0(0 \%)$ & $1(0.9 \%)$ & $0(0 \%)$ & $2(1.9 \%)$ & $0(0 \%)$ \\
\hline Not sure & $8(7.8 \%)$ & $2(7.7 \%)$ & $8(7.8 \%)$ & $1(3.9 \%)$ & $4(3.9 \%)$ & $0(0 \%)$ \\
\hline Total & $103(100 \%)$ & $26(100 \%)$ & $103(100 \%)$ & $26(100 \%)$ & $103(100 \%)$ & $26(100 \%)$ \\
\hline
\end{tabular}

Notes: $p$-value $=0.24 ; p$-value $=0.22 ; p$-value $=0.049 * *$ significant at $p<0.05$ 
Perhaps educators are more aware of resource constraints in academia, whereas practitioners may be more mindful of the need for forensic accounting education based on what they see in the field.

Survey participants were asked their opinion on whether forensic accounting education (as a separate course or as a concentration, major, minor or certificate) should be offered at the graduate level, undergraduate level, both or as postgraduate/continuing adult studies. As shown in Table IV, the majority of both groups agree that forensic accounting education should not be limited to one level, but should be offered at both the graduate and undergraduate levels. The greatest disparity in opinions was that practitioners are less likely than educators to believe forensic accounting education should be offered at only the graduate level. This difference might indicate that practitioners desire forensic accounting education to be available to as many students as possible, not only to graduate students.

\section{Obstacles to providing forensic accounting education}

Participants were asked to indicate to what degree they believe certain factors are obstacles to providing forensic accounting education. Responses were ranked on a five-point Likert scale, and are presented in Table $\mathrm{V}$.

Educators view lack of room in the accounting curriculum, lack of qualified faculty to teach forensic accounting courses and lack of administrative/financial support as the greatest obstacles, respectively.

Practitioners, while also viewing lack of room in the accounting curriculum as a perceived obstacle, did not consider it to be as much of an obstacle. The greatest significant difference was the perceived obstacle of lack of proper fit in accounting, with educators

\begin{tabular}{lcccc}
\hline Options for forensic accounting in the curriculum & Educators & Rank & Practitioners & Rank \\
\hline Separate course & $91(88.3 \%)$ & 1 & $19(73.1 \%)$ & 1 \\
Separate concentration, major, minor or certificate & $58(56.3 \%)$ & 2 & $18(69.2 \%)$ & 2 \\
Integrate throughout the accounting curriculum & $31(30.1 \%)$ & 3 & $16(61.5 \%)$ & 3 \\
Specific master's program & $30(29.1 \%)$ & 4 & $10(38.5 \%)$ & 4 \\
Specific doctorate program & $9(8.7 \%)$ & 5 & $2(7.7 \%)$ & 5 \\
Do not cover forensic accounting at all & $0(0.0 \%)$ & 6 & $0(0.0 \%)$ & 6 \\
Total responses & $219 *$ & & $65 *$ &
\end{tabular}

Notes: *Total $>$ number of respondents $(n=103$ for educators, $n=26$ for practitioners) because respondents were allowed to select as many responses as they believed applied

\section{Table III.}

Opinions on how forensic accounting should be integrated into the curriculum

\begin{tabular}{lcccc}
\hline Preferred level of forensic accounting education & Educators & Rank & Practitioners & Rank \\
\hline Both undergraduate and graduate levels & $62(60.2 \%)$ & 1 & $21(80.8 \%)$ & 1 \\
Graduate & $27(26.2 \%)$ & 2 & $2(7.7 \%)$ & 4 \\
Post graduate or continuing adult studies & $20(19.4 \%)$ & 3 & $5(19.2 \%)$ & 2 \\
Undergraduate & $9(8.7 \%)$ & 4 & $3(11.5 \%)$ & 3 \\
Total responses & $118^{*}$ & & $31^{*}$ &
\end{tabular}

Notes: *Total $>$ number of respondents ( $n=103$ for educators, $n=26$ for practitioners) because respondents were allowed to select as many responses as they believed applied

\section{Table IV.}

Opinions on preferred level of separate course or concentration/major/ minor/certificate in forensic accounting 
disagreeing more strongly. This finding may indicate that practitioners more readily view forensic accounting as a multidisciplinary field that could also be taught in departments other than accounting, such as criminal justice.

Both groups disagreed that lack of career opportunities or lack of student interest in forensic accounting are obstacles. A representative educator comment follows:

The single biggest challenge in the eyes of some students is that it is difficult to get a forensic accounting position right out of school. Most firms require two or three years of auditing to prepare a student for the world of forensic accounting practice and that is a long time for young people. Nonetheless, most students understand that is the normal career path and their chances for a forensic accounting career are greatly enhanced with a strong forensic accounting background from college.

Overall, the results suggest that the primary obstacles facing delivery of forensic accounting education are internal constraints (i.e. faculty, administration, curriculum structure), and not because of a perceived lack of demand in the marketplace or by students. Underscoring the importance of internal constraints, a representative educator comment follows:

The other business areas have been threatened by establishing a forensic accounting program. The program wasn't promoted properly, and the usual and incorrect mindset requires Ph.D. teachers in lieu of practitioners. All of this resulted in my program being terminated after three years.

\section{Forensic accounting education content}

Respondents were asked to give their opinion on the importance of 14 different content areas in forensic accounting, using a five-point Likert scale. Results are presented in Table VI, listing the topics in order of their mean response rankings by educators, from most to least important.

Given that the mean responses for all content areas are less than 3, both groups agreed that all 14 topics were important, although the rankings varied. Highly significant differences existed between the groups' views on the importance of including coverage of cybercrime and security, interviewing and interrogations and digital forensics, with practitioners considering those topics to be more important than educators. Emphasizing this finding, representative practitioner comments follow:

Fraud is always increasing and detection is getting more difficult with the change of technology. It is very important to increase awareness and strengthen the forensic accounting knowledge of students entering the field of accounting, and such education should be mandatory including interviewing/interrogating skills, which are extremely important.

Table V. Opinions on obstacles to including forensic accounting in the accounting curriculum

\begin{tabular}{|c|c|c|c|c|c|c|c|}
\hline \multirow{2}{*}{$\begin{array}{l}\text { Perceived obstacle } \\
\text { Lack of }\end{array}$} & \multirow[b]{2}{*}{$p$-value } & \multicolumn{3}{|c|}{ Educators } & \multicolumn{3}{|c|}{ Practitioners } \\
\hline & & Mean (rank) & Median & SD & Mean (rank) & Median & SD \\
\hline Room in curriculum & $0.017^{*}$ & $2.31(1)$ & 2.0 & 1.146 & $2.85(3)$ & 3.0 & 0.881 \\
\hline Qualified $\mathrm{f}$ & 0.99 & 2.37 & 2.0 & 1.15 & $2.38(2)$ & 2.0 & 1.203 \\
\hline Administrative/financial support & 0.99 & 2.63 & 2.0 & 1.336 & $2.23(1)$ & 2.0 & 0.765 \\
\hline Sufficient pedagogical materials & 0.99 & $3.17(4)$ & 3.0 & 1.336 & 2.85 (3) & 3.0 & 1.008 \\
\hline Career opportunities & 0.99 & $4.01(5)$ & 4.0 & 1.217 & $4.00(7)$ & 4.0 & 1.020 \\
\hline Student interest & 0.13 & $4.07(6)$ & 5.0 & 1.231 & $3.54(6)$ & 4.0 & 1.104 \\
\hline Proper fit in accounting & $0.008 * *$ & $4.12(7)$ & 5.0 & 1.163 & $3.38(5)$ & 4.0 & 1.169 \\
\hline
\end{tabular}

Notes: $1=$ strongly agree this is an obstacle; $3=$ neutral; $5=$ strongly disagree; *ignificant at $p<0.05$; ***highly significant at $p<0.01$ 


\begin{tabular}{|c|c|c|c|c|c|c|c|c|}
\hline \multirow[b]{2}{*}{ Content area } & \multirow[b]{2}{*}{$p$-value } & \multicolumn{2}{|c|}{ Educators } & \multicolumn{3}{|c|}{ Practitioners } & \multirow[b]{2}{*}{ SD } & \\
\hline & & Mean (rank) & Median & $\mathrm{SD}$ & Mean (rank) & Median & & \\
\hline Fraud detection methods & 0.99 & $1.38(1)$ & 1.0 & 0.856 & $1.15(2)$ & 1.0 & 0.368 & \\
\hline Asset misappropriation & 0.99 & $1.39(2)$ & 1.0 & 0.883 & $1.31(8)$ & 1.0 & 0.549 & \\
\hline \multicolumn{9}{|l|}{ Fraudulent financial statements } \\
\hline Fraud prevention/deterrence & 0.49 & $1.41(4)$ & 1.0 & 0.873 & $1.08(1)$ & 1.0 & 0.272 & \\
\hline \multicolumn{9}{|l|}{$\begin{array}{l}\text { Fraud investigation methods, } \\
\text { including the organization and }\end{array}$} \\
\hline evaluation of evidence & 0.71 & $1.51(5)$ & 1.0 & 0.877 & $1.19(6)$ & 1.0 & 0.402 & \\
\hline Corruption & 0.70 & $1.68(6)$ & 1.0 & 0.934 & $1.31(8)$ & 1.0 & 0.471 & \\
\hline Cybercrime and security & $0.0023^{* * *}$ & $1.78(7)$ & 2.0 & 0.897 & $1.15(2)$ & 1.0 & 0.368 & \\
\hline Data analytic software (e.g. IDEA) & 0.71 & $1.79(8)$ & 2.0 & 0.828 & $1.50(10)$ & 1.0 & 0.648 & \\
\hline Interviewing and interrogations & $4.5 \mathrm{e}-3^{* *}$ & $1.82(9)$ & 2.0 & 0.894 & $1.15(2)$ & 1.0 & 0.368 & \\
\hline Digital forensics & $4.1 \mathrm{e}-4^{* *}$ & $1.94(10)$ & 2.0 & 0.812 & $1.27(7)$ & 1.0 & 0.452 & \\
\hline Criminology, the legal environment & $\begin{array}{l}0.99 \\
0.99\end{array}$ & $\begin{array}{l}2.00(11) \\
2.05(12)\end{array}$ & $\begin{array}{l}2.0 \\
2.0\end{array}$ & $\begin{array}{l}0.972 \\
0.896\end{array}$ & $\begin{array}{l}1.73(12) \\
1.81(13)\end{array}$ & $\begin{array}{l}2.0 \\
2.0\end{array}$ & $\begin{array}{l}0.667 \\
0.694\end{array}$ & \\
\hline \multirow{2}{*}{$\begin{array}{l}\text { Forensic psychology, profiling and } \\
\text { the fraud mindset } \\
\text { Remediation and conflict } \\
\text { resolution }\end{array}$} & 0.49 & $2.13(13)$ & 2.0 & 0.968 & $1.65(11)$ & 1.0 & 0.745 & $\begin{array}{r}\text { Table VI. } \\
\text { Opinions on }\end{array}$ \\
\hline & 0.99 & $2.52(14)$ & 2.0 & 0.927 & $2.23(14)$ & 2.0 & 0.908 & $\begin{array}{r}\text { importance of } \\
\text { various content areas }\end{array}$ \\
\hline \multicolumn{8}{|c|}{$\begin{array}{l}\text { Notes: } 1=\text { very important; } 3=\text { average importance; } 5=\text { not at all important; }{ }^{*} \text { significant at } p<0.05 \text {; } \\
* * \text { highly significant at } p<0.01\end{array}$} & $\begin{array}{l}\text { in forensic } \\
\text { accounting education }\end{array}$ \\
\hline
\end{tabular}

As the world continues to move toward a more electronic environment, the ability to commit fraud will continue to be more prevalent and the need for forensic accountants with forensic computer skills will continue to grow. Also, I highly recommend emphasis on developing interviewing skills in forensic accounting classes.

This view by practitioners that interviewing skills are critical in forensic accounting is consistent with Buckhoff and Hansen's (2002) experience that those who have the skills to effectively conduct interviews will be more successful in the forensic accounting field.

\section{Educators' current forensic accounting content}

Next, only educators were asked to indicate the degree of coverage they give each of the aforementioned 14 topic areas in their forensic accounting courses. A five-point Likert scale was used, and results are presented in Table VII, along with the educators' opinion on the importance of the 14 topics reproduced from Table VI.

Highly significant differences between the relative importance and actual coverage educators give topics were found with the following five areas:

(1) data analytic software;

(2) cybercrime and security;

(3) digital forensics;

(4) valuation of losses and damages; and

(5) remediation and conflict resolution.

These topics are out of mainstream accounting and require knowledge in specialized areas within the field of forensic accounting (e.g. expertise in computers or law) that the typical 


\begin{tabular}{|c|c|c|c|c|c|c|c|}
\hline \multirow[b]{2}{*}{ Content area } & \multirow[b]{2}{*}{$p$-value } & \multicolumn{3}{|c|}{$\begin{array}{l}\text { Educators' coverage of } \\
\text { content in their course(s) }\end{array}$} & \multicolumn{3}{|c|}{$\begin{array}{c}\text { Educators' opinion on } \\
\text { importance of content (from } \\
\text { Table VI) }\end{array}$} \\
\hline & & Mean (rank) & Median & SD & Mean (rank) & Median & $\mathrm{SD}$ \\
\hline Fraud prevention/deterrence & 0.76 & $1.53(1)$ & 1.0 & 0.951 & $1.41(4)$ & 1.0 & 0.873 \\
\hline Asset misappropriation & & $1.58(2)$ & 1.0 & 1.016 & $1.39(2)$ & 1.0 & 0.883 \\
\hline Fraudulent financial statements & 076 & $160(3)$ & 10 & 0.969 & $140(3)$ & 10 & 0.790 \\
\hline Fraud detection methods & 0.56 & $1.63(4)$ & 1.0 & 1.038 & $1.38(1)$ & 1.0 & 0.856 \\
\hline $\begin{array}{l}\text { Fraud investigation methods, } \\
\text { including the organization and }\end{array}$ & & & & & & & \\
\hline $\begin{array}{l}\text { evaluation o } \\
\text { Corruption }\end{array}$ & $\begin{array}{l}0.37 \\
0.32\end{array}$ & $\begin{array}{l}1.90(5) \\
2.06(6)\end{array}$ & $\begin{array}{l}2.0 \\
2.0\end{array}$ & $\begin{array}{l}1.092 \\
0.987\end{array}$ & $\begin{array}{l}1.51(5) \\
1.68(6)\end{array}$ & $\begin{array}{l}1.0 \\
1.0\end{array}$ & $\begin{array}{l}0.877 \\
0.934\end{array}$ \\
\hline Interviewing and interrogations & 0.37 & $2.22(7)$ & 2.0 & 1.222 & $1.82(9)$ & 2.0 & 0.894 \\
\hline $\begin{array}{l}\text { Criminology, the legal environment } \\
\text { and ethical issues } \\
\text { Forensic psvchology profiling and }\end{array}$ & 0.48 & $2.42(8)$ & 2.0 & 1.241 & $2.00(11)$ & 2.0 & 0.972 \\
\hline the fraud mindset & 0.32 & $2.65(9)$ & 2.0 & 1.169 & $2.13(13)$ & 2.0 & 0.968 \\
\hline Data analytic software (e.g. IDEA) & $1.8 \mathrm{e}-05^{* *}$ & $2.79(10)$ & 3.0 & 1.386 & $1.79(8)$ & 2.0 & 0.828 \\
\hline Cybercrime and security & $3.4 \mathrm{e}-06 * *$ & 2.85 (11) & 3.0 & 1.336 & $1.78(7)$ & 2.0 & 0.897 \\
\hline Digital forensics & $2.7 \mathrm{e}-07 * *$ & $3.04(12)$ & 3.0 & 1.413 & $1.94(10)$ & 2.0 & 0.812 \\
\hline Valuation of losses and damages & $1.2 \mathrm{e}-06^{* *}$ & 3.19 (13) & 3.0 & 1.484 & $2.05(12)$ & 2.0 & 0.896 \\
\hline resolution & $1.6 \mathrm{e}-07 * *$ & $3.62(14)$ & 4.0 & 1.312 & $2.52(14)$ & 2.0 & 0.927 \\
\hline
\end{tabular}

Table VII.

Degree of coverage of various content areas in respondents' forensic accounting courses
Notes: $1=$ strongly covered; $3=$ average coverage; $5=$ not covered; ${ }^{a}(1=$ very important; $3=$ average importance; $5=$ not at all important; $* *$ highly significant at $p<0.01$

accounting professor probably does not possess, which supports the earlier finding that lack of qualified faculty is one of the perceived obstacles to providing forensic accounting education.

The educator respondents, however, overwhelmingly indicated that the forensic accounting course(s) at their institution has been favorably received (87 of the 93 responses, or 93.5 per cent; there were 10 nonresponses). Only six instructors replied that the course had not been favorably received, and these respondents typically suggested that lack of resources was a problem, as follows:

I wish I could say that inclusion of forensic courses has been mostly favorable. Some faculty object because resources are scarce.

Representative educator comments with positive experiences follow:

Fraud Examination/Forensic Accounting has been a great addition to our curriculum! We are getting ready to roll out a second/advanced course next fall.

Our forensic accounting course is one of the most popular courses we offer.

\section{Teaching techniques with forensic accounting}

Respondents were asked to give their opinions on the importance of various manners to teach forensic accounting. Practitioners were included because they have experience from which to draw their conclusions. Results are presented in Table VIII, in ranked order by the educators' mean responses. 


\begin{tabular}{|c|c|c|c|c|c|c|c|c|}
\hline \multirow[b]{2}{*}{ Teaching technique } & \multirow[b]{2}{*}{$p$-value } & \multicolumn{2}{|c|}{ Educators } & \multicolumn{3}{|c|}{ Practitioners } & \multirow[b]{2}{*}{ SD } & \\
\hline & & Mean (rank) & Median & SD & Mean (rank) & Median & & \\
\hline Case studies & 0.99 & $1.45(1)$ & 1.0 & 0.879 & $1.23(1)$ & 1.0 & 0.430 & \\
\hline $\begin{array}{l}\text { Problem-based learning cases and } \\
\text { simulations }\end{array}$ & 0.99 & $1.66(2)$ & 1.0 & 1.077 & $1.31(2)$ & 1.0 & 0.471 & \\
\hline $\begin{array}{l}\text { Student research projects and } \\
\text { presentations }\end{array}$ & 0.99 & $2.08(3)$ & 2.0 & 1.208 & $1.81(9)$ & 2.0 & 0.749 & \\
\hline $\begin{array}{l}\text { Textbook and supplemental } \\
\text { resources (e.g. test bank) }\end{array}$ & 0.99 & $2.09(4)$ & 2.0 & 1.210 & $1.73(8)$ & 2.0 & 0.724 & \\
\hline Guest lecturers & 0.10 & $2.10(5)$ & 2.0 & 1.227 & $1.42(4)$ & 1.0 & 0.578 & \\
\hline Videos & 0.99 & $2.16(6)$ & 2.0 & 1.217 & 1.85 (11) & 2.0 & 0.967 & \\
\hline Self-developed materials & 0.99 & $2.34(7)$ & 2.0 & 1.195 & $2.35(16)$ & 3.0 & 1.018 & \\
\hline Data analytic software (e.g. IDEA) & $4.2 \mathrm{e}-3^{* * *}$ & $2.52(8)$ & 2.0 & 1.294 & $1.46(6)$ & 1.0 & 0.647 & \\
\hline Role-playing scenarios & $1.4 \mathrm{e}-2^{*}$ & $2.73(9)$ & 2.0 & 1.283 & $1.81(9)$ & 2.0 & 0.895 & \\
\hline $\begin{array}{l}\text { Digital forensic software (e.g. Data } \\
\text { Recovery) }\end{array}$ & & & & & & & & \\
\hline $\begin{array}{l}\text { Recovery) } \\
\text { Internships }\end{array}$ & $\begin{array}{l}2.4 \mathrm{e}-7 \\
6.1 \mathrm{e}-6^{* *}\end{array}$ & $\begin{array}{l}3.06(10) \\
3.07(11)\end{array}$ & $\begin{array}{l}3.0 \\
3.0\end{array}$ & $\begin{array}{l}1.246 \\
1.444\end{array}$ & $\begin{array}{l}1.38(3) \\
1.42(4)\end{array}$ & $\begin{array}{l}1.0 \\
1.0\end{array}$ & $\begin{array}{l}0.571 \\
0.578\end{array}$ & \\
\hline Co-teaching & $8.3 \mathrm{e}-4^{* *}$ & $3.43(12)$ & 4.0 & 1.440 & $2.04(13)$ & 2.0 & 0.958 & Table VIII. \\
\hline Service learning activities & $4.3 \mathrm{e}-5^{* *}$ & 3.49 (13) & 4.0 & 1.294 & $2.08(14)$ & 2.0 & 0.744 & Opinions on \\
\hline Field trips & $7.5 e-4^{* *}$ & 3.55 (14) & 4.0 & 1.279 & 2.31 (15) & 2.0 & 1.050 & importance of \\
\hline Computer forensics lab & $4.1 e-7^{* *}$ & $3.60(15)$ & 4.0 & 1.371 & $1.54(7)$ & 1.0 & 0.811 & various teaching \\
\hline Moot court activities & $2.9 \mathrm{e}-5^{* *}$ & 3.60 (15) & 4.0 & 1.428 & $2.00(12)$ & 2.0 & 0.800 & techniques for \\
\hline $\begin{array}{l}\text { Notes: } 1=\text { very important; } 3= \\
* * \text { highly significant at } p<0.01\end{array}$ & rage im & rtance; $5=$ & not at all & import & $\operatorname{tant;}$ *signific & ant at $p$. & 0.05 & $\begin{array}{r}\text { forensic accounting } \\
\text { education }\end{array}$ \\
\hline
\end{tabular}

A five-point Likert scale, where a " 3 " signifies "average importance" was used. Because the practitioners' mean responses for all 16 teaching techniques are less than 3 , the results show that the practitioners believe all techniques are important, unlike the educators.

Statistically significant differences between the groups were found with the following nine techniques: role-playing scenarios, data analytic software, digital forensic software, internships, co-teaching, service learning activities, field trips, computer forensics lab and moot court activities. The practitioners consider these nine techniques to be more important than the educators, suggesting that, in general, the practitioners more highly value techniques that add an experiential or "real world" learning component and more highly value computer forensic skills.

A possible explanation for why educators rated these techniques as less important is many of these methods are not in the skill set of most accounting faculty. For example, several methods require some computer knowledge and skills, in addition to the necessary hardware and software that may not be available at the college. Similarly, moot court activities require some knowledge of the law. As the earlier results found, lack of qualified faculty and lack of financial support are considered to be obstacles by educators to providing this education. However, it could be possible for some universities to work with other disciplines, such as computer science or law, to overcome these hurdles. Using volunteers from the local legal community for moot court activities is another possibility (Crumbley, 2010).

Service learning activities could require extensive knowledge in all areas of forensic accounting, depending upon the activity. In addition, these activities might be very timeconsuming for the instructor, raising the obstacle of lack of administrative/financial support. 
However, faculty who have implemented this technique in forensic accounting classes have reported it to be quite rewarding (Riley et al., 2011).

\section{Factors contributing to a successful forensic accounting program}

Respondents were asked to rank six factors that might contribute to a successful forensic accounting program, and the results are presented in Table IX in order of importance as indicated by educators.

Both groups agree on the top three factors (strong student interest/high enrollment; qualified faculty and career opportunities for students with this education), although in slightly different order. Both groups agree with the rankings of the last three items: partnerships with law enforcement, governmental agencies and/or CPA firms; an internship program; and service learning activities, ranked fourth, fifth and sixth, respectively.

Significant differences were found with the factors of career opportunities for students, service learning activities and strong student interest. Practitioners considered career opportunities to be more important, perhaps suggesting they hold a pragmatic view of the end result of this education. On the other hand, educators considered strong student interest/high enrollment to be the most important factor for success, suggesting they also hold a pragmatic view from their perspective, as low enrollments could cause cancellation of the course(s).

\section{Concluding remarks}

The results in this paper can help educators who have not considered offering forensic accounting courses or who wish to refine or update their existing forensic accounting education. Students seeking a career in forensic accounting can also use these results to facilitate their course choices to develop skills valued by employers. Academicians and practitioners strongly agree on the importance of including forensic accounting education in the accounting curriculum, as it is an important field that is experiencing tremendous growth and student interest is high. Perhaps this sentiment is most clearly expressed by the following representative practitioner comment:

I believe there is a strong need to provide forensic accounting to accounting students. I graduated with a BS in Forensic Accounting and I absolutely loved the program! I have used my forensic accounting skills on several projects.

Table IX.

Opinions on importance of various factors contributing to the success of forensic accounting education

\begin{tabular}{|c|c|c|c|c|c|c|c|}
\hline \multirow[b]{2}{*}{ Factor } & \multirow[b]{2}{*}{$p$-value } & \multicolumn{3}{|c|}{ Educators } & \multicolumn{3}{|c|}{ Practitioners } \\
\hline & & Mean (rank) & Median & $\mathrm{SD}$ & Mean (rank) & Median & $\mathrm{SD}$ \\
\hline $\begin{array}{l}\text { Strong student interest (high } \\
\text { enrollment in course/program) }\end{array}$ & $2.5 \mathrm{e}-3^{* * *}$ & $1.72(1)$ & 1.0 & 1.048 & $2.62(3)$ & 3.0 & 1.299 \\
\hline Qualified faculty & 0.11 & $2.16(2)$ & 2.0 & 1.235 & $1.62(1)$ & 2.0 & 0.637 \\
\hline $\begin{array}{l}\text { Career opportunities for students } \\
\text { with this education }\end{array}$ & $0.02^{*}$ & $3.26(3)$ & 3.0 & 1.210 & $2.38(2)$ & 2.0 & 1.134 \\
\hline $\begin{array}{l}\text { Partnerships with law } \\
\text { enforcement, governmental } \\
\text { agencies and/or CPA firms }\end{array}$ & 0.94 & $4.08(4)$ & 4.0 & 1.365 & $4.00(4)$ & 4.0 & 0.849 \\
\hline Internship program & 0.94 & $4.84(5)$ & 5.0 & 1.083 & $4.77(5)$ & 5.0 & 1.032 \\
\hline Service learning activities & $0.04^{*}$ & $4.94(6)$ & 5.0 & 1.120 & $5.38(6)$ & 6.0 & 1.134 \\
\hline
\end{tabular}

Notes: * Significant at $p<0.05 ; * *$ highly significant at $p<0.01 ; 1=$ most important; $2=$ second most important; etc., up to $6=$ least important 
Educators also note that forensic accounting skills are useful for students, even if they do not pursue a forensic accounting career path, as these two typical comments illustrate:

An auditing career is one of the most important options accounting students prefer to take and forensic accounting will add value to the quality of auditing.

Forensic Accounting is a vastly important field that is experiencing tremendous growth. All accounting students, regardless of future employment (audit, tax, etc.), can benefit greatly from the skills learned in a forensic accounting class.

Respondents agree that resources are scarce and a lack of qualified faculty to teach forensic accounting is a major obstacle. This need was a recurring theme in the educators' comments, with typical responses such as these:

The litigation support universe is where most forensic accounting is performed and is largely ignored in most textbooks for many reasons. Professors teaching these courses need to have consulting practices of their own to really understand the topic. It is NOT purely academic.

We have an undergraduate elective course and a graduate required course. It's a growing field and student interest is high - resources are scarce, though, as are qualified faculty (CFEs or anyone with related experience). It's not something you can just teach from a textbook.

We would like to expand our program from one graduate course to a concentration. We just need one more faculty member to jump-start the push. Those are in short supply.

Practitioners view the topic areas of cybercrime and security, digital forensics and interviewing and interrogations as significantly more important to include in forensic accounting education. These topic areas are outside of traditional accounting, perhaps influencing educators' ratings of importance and influencing the relatively lower coverage this study finds they give those topics.

A possible solution to address the lack of qualified faculty and that might also allow more nontraditional accounting topics to be taught in a forensic accounting course or program would be to develop interdisciplinary programs with other departments, such as criminal justice, computer science, information systems and law. It is important for schools to identify their primary stakeholders, in addition to the core competencies, knowledge and skills most highly valued by their students' employers. This information can drive a school's decision about which departments to collaborate with when developing their forensic accounting education.

\section{Limitations and directions for future research}

An inherent limitation of any survey research is that results are subject to a possible nonresponse bias. This sample could be biased because of the small response rate and any observed differences could represent a very special subset of practitioners and educators. To test for nonresponse bias, later responses were compared with earlier responses and no significant differences were found. Forensic accounting is a broad field and the survey questions were limited in an attempt to obtain a higher response rate than if many more questions had been asked. For example, the content areas shown in Table VI were selected based on a literature review and a review of two current forensic accounting textbooks. No claim is made that these areas are a complete listing of all possible forensic accounting topics, and as such, there could be additional topics the respondents might have considered important, although none was mentioned in the open-ended comment section.

Given the explosive growth in forensic accounting education over the past decade, future research could examine the syllabi of forensic accounting educators and determine exactly 
what content areas are being covered and what teaching techniques are used. In addition, very little research exists pertaining to international forensic accounting education. Future research could examine the views of international forensic accounting educators, and compare their views and practices to that of US educators as well as forensic accounting practitioners, both internationally and within the USA Also, research regarding the job placements, including starting salaries, of graduates from forensic accounting education programs could provide helpful information about knowledge and skills valued by employers. This research would discover what recruiters of forensic accounting program graduates find to be the strengths and weaknesses of their new employees.

\section{Note}

1. The focus of this paper is on education in forensic accounting, rather than fraud examination. A recent text by several forensic accounting practitioners states, "Forensic accounting definitions commonly refer to fraud, fraud prevention, and fraud investigations as the role of the forensic accountant [...] Fraud is only one context where the skills of forensic accounting can prove invaluable - there are many, many other contexts beyond fraud to which forensic accounting applies [...] Perhaps Crumbley, Heitger, and Stevenson Smith in their book Forensic and Investigative Accounting, Second Edition, provide the clearest and most concise definition of forensic accounting: "Forensic accounting is the use of accounting for legal purposes"' (Silverstone et al., 2012, pp. 3-4). In an interview with Joseph Wells, founder of the ACFE, he is asked, "Many in the accounting profession use the terms 'forensic accounting' and 'fraud examination' interchangeably. What is the difference?" He replies," "Forensic accounting' is the application of any accounting technique for courtroom purposes. It can involve fraud, bankruptcy, damages, valuation, or a host of other issues not connected with fraud. 'Fraud examination' is the application of specific procedures to resolve allegations of fraud, from inception to disposition. Fraud examiners gather evidence, take statements, prepare reports, testify to findings, and assist in the detection and deterrence of fraud. Although 'forensic accounting' is frequently used as a euphemism for 'fraud examination', the former is a much broader term. Moreover, fraud examinations are commonly conducted by professionals with a nonaccounting background" (Kranacher, 2006).

\section{References}

Apostolou, B., Hassell, J., Rebele, J. and Watson, S. (2010), “Accounting education literature review (2006-2009)”, Journal of Accounting Education, Vol. 28 Nos 3/4, pp. 145-197.

ACFE (2014), "Report to the nations on occupational fraud and abuse", available at: www.acfe.com/rttn. aspx (accessed 24 October 2015).

Buckhoff, T. and Hansen, J. (2002), "Interviewing as a 'forensic-type' procedure”, Journal of Forensic Accounting, Vol. 3 No. 1, pp. 1-15.

Buckhoff, T. and Schrader, R. (2000), "The teaching of forensic accounting in the United States", Journal of Forensic Accounting, Vol. 1 No. 1, pp. 135-146.

Bundy, T., Ward, S. and Ward, D. (2003), "Forensic accounting: the profession's new growth industry", Journal of Business, Industry and Economics, Vol. 3 No. 1, pp. 29-38.

Carnes, K. and Gierlasinski, N. (2001), "Forensic accounting skills: will supply finally catch up to demand?”, Managerial Auditing Journal, Vol. 16 No. 6, pp. 378-382.

Carozza, D. (2002), "Accounting students must have armor of fraud examination", The White Paper: Topical Issues on White-Collar Crime, Vol. 16 No. 1, pp. 30-33.

Carpenter, T., Durtschi, C. and Gaynor, L. (2011), "The incremental benefits of a forensic accounting course on skepticism and fraud-related judgments", Issues in Accounting Education, Vol. 26 No. 1, pp. 1-21. 
Cohn, M. (2014), "Demand growing for forensic accountants", available at: www.accountingtoday.com/blogs/ debits-credits/demand-growing-for-forensic-accountants-71116-1.html (accessed 24 October 2015).

Crumbley, D.L. (2010), "Mock trials are fun, informative, and educational", available at: www.bus.lsu. edu/accounting/faculty/lcrumbley/jfia/Articles/v2n1.htm (accessed 7 December 2015).

Crumbley, D.L., Heitger, L. and Smith, S. (2013), Forensic and Investigative Accounting, 6th ed., CCH, Chicago, IL.

Curtis, G. (2008), "Legal and regulatory environments and ethics: essential components of a fraud and forensic accounting curriculum”, Issues in Accounting Education, Vol. 23 No. 4, pp. 535-543.

Davis, C., Farrell, R. and Ogilby, S. (2009), Characteristics and Skills of the Forensic Accountant, AICPA Forensics and Valuation Services, New York, NY.

DiGabriele, J. (2008), “An empirical investigation of the relevant skills of forensic accountants”, Journal of Education for Business, Vol. 83 No. 6, pp. 331-340.

E\&Y (2014), "Overcoming compliance fatigue: reinforcing the commitment to ethical growth, 13th global fraud survey", available at: ww.ey.com/GL/en/Services/Assurance/Fraud-InvestigationDispute-Services/EY-reinforcing-the-commitment-to-ethical-growth (accessed 24 October 2015).

Fowler, E. (1991), "Careers: 'forensic accountants' in demand”, available at: www.nytimes.com/1991/07/ 16/business/careers-forensic-accountants-in-demand.html (accessed 24 October 2015).

Hasselback, J. (2015), Accounting Directory 2014-2015, Pearson Education, Hoboken, NJ.

Heitger, L. and Heitger, D. (2008), "Incorporating forensic accounting and litigation advisory services into the classroom", Issues in Accounting Education, Vol. 23 No. 4, pp. 561-572.

Holm, S. (1979), "A simple sequentially rejective multiple test procedure", Scandinavian Journal of Statistics, Vol. 6 No. 2, pp. 65-70.

Hopwood, W., Leiner, J. and Young, G. (2012), Forensic Accounting and Fraud Examination, 2nd ed., McGraw-Hill/Irwin, Boston, MA.

Houck, M., Kranacher, M.-J., Morris, B., Riley, R., Robertson, J. and Wells, J. (2006), "Forensic accounting as an investigative tool: developing a model curriculum for fraud and forensic accounting", The CPA Journal, Vol. 76 No. 8, pp. 68-76.

KPMG (2013), "Integrity survey”, available at: www.kpmg.com/cn/en/issuesandinsights/ articlespublications/pages/integrity-survey-2013-o-201307.aspx (accessed 24 October 2015).

Kranacher, M.-J. (2006), "The battle against fraud: seeking the accounting profession's support", available at: http://archives.cpajournal.com/2006/906/index.htm (accessed 24 October 2015).

Levine, S. (2002), “Careers to count on”, U.S. News \& World Report, 18 February, p. 46.

McMullan, D. and Sanchez, M. (2010), "A preliminary investigation of the necessary skills, education requirements, and training requirements for forensic accountants", Journal of Forensic \& Investigative Accounting, Vol. 2 No. 2, pp. 30-48.

MacDonald, E. (1996), "Accounting sleuths ferret hidden assets", The Wall Street Journal, (18 December), pp. B1-B2.

Melancon, B. (2002), “A new accounting culture”, Journal of Accountancy, Vol. 194 No. 4, pp. 27-30.

Meservy, R., Romney, M. and Zimbelman, M. (2006), "Certified fraud examiners: a survey of their training, experience and curriculum recommendations", Journal of Forensic Accounting, Vol. 7 No. 1, pp. 163-184.

Mounce, P. and Frazier, J. (2002), "The effect of forensic accounting education on an accountant's employment potential", Journal of Forensic Accounting, Vol. 3 No. 1, pp. 91-102.

Pearson, T. and Singleton, T. (2008), "Fraud and forensic accounting in the digital environment", Issues in Accounting Education, Vol. 23 No. 4, pp. 545-559.

Peterson, B. and Buckhoff, T. (2004), "Anti-fraud education in academia", Advances in Accounting Education: Teaching and Curriculum Innovations, Vol. 6, pp. 45-67. 
Peterson, B. and Reider, B. (1999), "Fraud education of accounting students: a survey of accounting educators", The National Accounting Journal, Vol. 1 No. 1, pp. 23-30.

Peterson, B. and Reider, B. (2001), "An examination of forensic accounting courses: content and learning activities”, Journal of Forensic Accounting, Vol. 2 No. 1, pp. 25-41.

PwC (2014), "Global economic crime survey", available at: www.pwc.com/gx/en/economic-crimesurvey/index.jhtml (accessed 24 October 2015).

Ramamoorti, S. (2008), "The psychology and sociology of fraud: integrating the behavioral sciences component into fraud and forensic accounting curricula", Issues in Accounting Education, Vol. 23 No. 4, pp. 521-533.

Rebele, J., Apostolou, B., Buckless, F., Hassell, J., Paquette, L. and Stout, D. (1998), "Accounting education literature review (1991-1997), part 1: curriculum and instructional approaches", Journal of Accounting Education, Vol. 16 No. 1, pp. 1-51.

Rezaee, Z., Crumbley, D. and Elmore, R. (2004), "Forensic accounting education: a survey of academicians and practitioners", Advances in Accounting Education, Vol. 6, pp. 193-231.

Rezaee, Z., Lander, G. and Reinstein, A. (1996), "Integrating forensic accounting into the accounting curriculum", Accounting Education: A Journal of Theory, Practice and Research, Vol. 1 No. 2, pp. 147-162.

Riley, R., Melendy, S. and Doran, M. (2011), "Service learning activities: students putting their skills on the line to assist real companies", Fraud Magazine, Vol. 26 No. 4, pp. 14-16.

Seda, M. and Kramer, B. (2008), "The emergence of forensic accounting programs in higher education", Management Accounting Quarterly, Vol. 9 No. 3, pp. 15-23.

Seda, M. and Kramer, B. (2009), "State of forensic accounting tracks at the university undergraduate/ graduate levels and the related need to change the educational model used in accounting", Journal of Forensic Studies in Accounting and Business, Vol. 1 No. 1, pp. 23-50.

Seda, M. and Kramer, B. (2014), "An examination of the availability and composition of forensic accounting education in the United States and other countries", Journal of Forensic \& Investigative Accounting, Vol. 6 No. 1, pp. 1-46.

Shaffer, J. (1995), "Multiple hypothesis testing”, Annual Review of Psychology, Vol. 46 No. 1, pp. 561-576.

Silverstone, H., Sheetz, M., Pedneault, S. and Rudewicz, R. (2012), Forensic Accounting and Frand Investigation for Non-Experts, 3rd ed., John Wiley \& Sons, Hoboken, NJ.

Smith, G. and Crumbley, D. (2009), "How divergent are pedagogical views towards fraud/forensic accounting curriculum?", Global Perspectives on Accounting Education, Vol. 6, pp. 1-24.

Tysiac, K. (2012), "Demand strong for forensic accountants in wake of financial crisis", available at: www.cpa2biz.com/Content/media/PRODUCER_CONTENT/Newsletters/Articles_2012/ CPA/Sep/ForensicAccounting.jsp (accessed 24 October 2015).

WVU (2007), "Education and training in fraud and forensic accounting: a guide for educational institutions, stakeholder organizations, faculty, and students", available at: www.ncjrs.gov/ pdffiles1/nij/grants/217589.pdf (accessed 24 October 2015).

White, D. (2013), "Demand for 'CPA sleuths' on the rise", available at: www.accountingweb.com/article/ demand-cpa-sleuths-rise/222901 (accessed 24 October 2015).

\section{Corresponding author}

Bonita Kramer can be contacted at: bonitap@montana.edu 